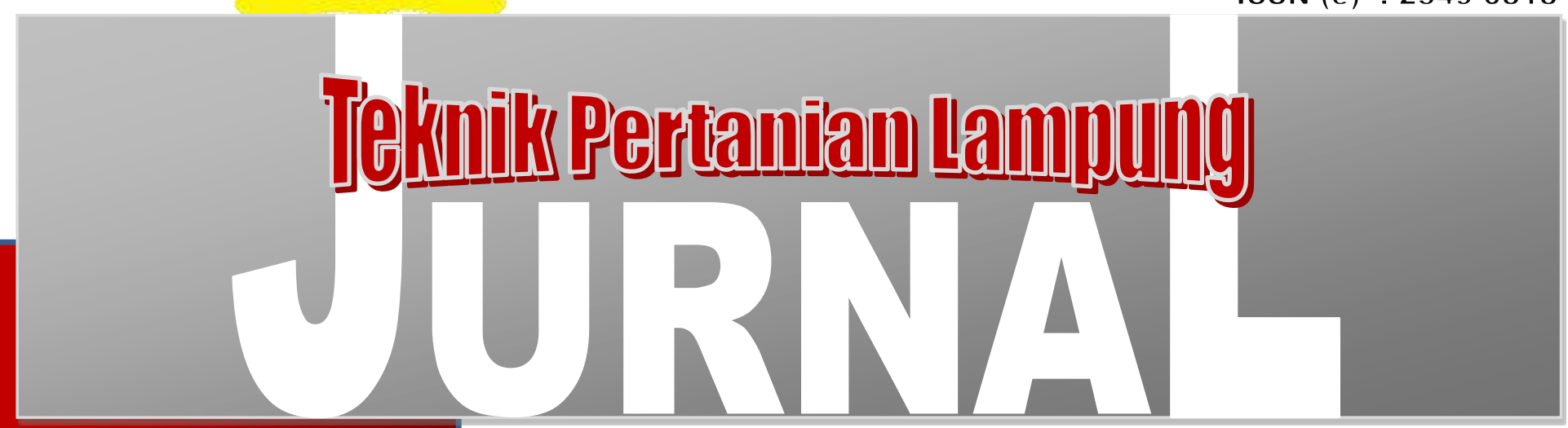

Vol. 7, No. 2, Agustus 2018 


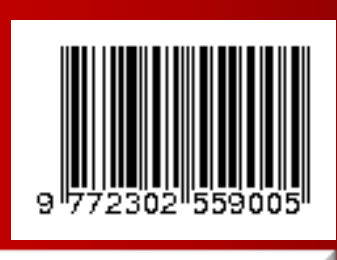


ISSN (p): 2302-559X

ISSN (e): 2549-0818

\section{Geanal TEKNIK PERTANIAN LAMPUNG}

\section{Vol. 7 No. 2, Agustus 2018}

Jurnal Teknik Pertanian (J-TEP) merupakan publikasi ilmiah yang memuat hasil-hasil penelitian, pengembangan, kajian atau gagasan dalam bidang keteknikan pertanian. Lingkup penulisan karya ilmiah dalam jurnal ini antara lain: rekayasa sumber daya air dan lahan, bangunan dan lingkungan pertanian, rekayasa bioproses dan penanganan pasca panen, daya dan alat mesin pertanian, energy terbarukan, dan system kendali dan kecerdasan buatan dalam bidang pertanian. J-TEP terbit sebanyak 3 (tiga) kali dalam satu tahun. Mulai tahun 2018 J-TEP menerbitkan jurnla pada bulan April, Agustus, dan Desember. J-TEP terbuka untuk umum, peneliti, mahasiswa, praktisi, dan pemerhati dalam dunia keteknikan pertanian.

\section{Ketua Editor}

Dr. Ir. Agus Haryanto, M.P

\section{Reviewer}

Prof. Dr. Ir, R.A. Bustomi Rosadi, M.S. (Manajemen Irigasi, Universitas Lampung)

Prof. Dr. Ir. Udin Hasanudin, M.T (Pengelolaan Limbah Agroindustri, Universitas Lampung)

Ir. Mimin Muhaemin, M.Eng., Ph.D (Mekanisasi Pertanian, Universitas Padjajaran)

Dr. Ir. Sugeng Triyono, M.Sc. (Rekayasa Sumberdaya Lahan dan Air, Universitas Lampung)

Dr. Eng Muhammad Makky (Teknik Biosistem, Universitas Andalas)

Dr. Diding Suhandy, S.TP., M.Agr (Spektroskopi, Universitas Lampung)

Dr. Ir. Wiludjeng Trisasiwi, MP (Energi Terbarukan, Universitas Jenderal Soedirman)

Dr. Sri Rahayoe, S.TP, M.P (Pengolahan Pangan, Universitas Gadjah Mada)

\section{Dewan Redaksi}

Ketua : Ahmad Tusi, S.TP, M.Si

Sekretaris : Cicih Sugianti, S.TP, M.Si

Anggota : Dr. Mareli Telaumbanuwa, S.TP, M.Sc

Winda Rahmawati, S.TP, M.Si., M.Sc

Tri Wahyu Saputra, S.T.P. M.Sc.

Jurnal Teknik Pertanian diterbitkan oleh Jurusan Teknik Pertanian, Universitas Lampung.

\section{Alamat Redaksi J-TEP:}

Jurusan Teknik Pertanian, Fakultas Pertanian

Universitas Lampung

Jl. Soemantri Brodjonegoro No.1

Telp. 0721-701609 ext. 846

Website :http://jurnal.fp.unila.ac.id/index.php/JTP

Email :jurnal tep@fp.unila.ac.id dan ae.journal@yahoo.com 


\section{PENGANTAR REDAKSI}

Dengan mengucapkan puji syukur kepada Allah yang Maha Kuasa, Jurnal Teknik Pertanian (JTEP) Volume 7 No 2 Tahun 2018 dapat diterbitkan. Pada edisi kali ini dimuat 7 (tujuh) artikel yang merupakan karya tulis ilmiah dari berbagai bidang kajian dalam dunia Keteknikan Pertanian yang meliputi modifikasi mesin peniris minyak dan analisis kelayakan produksi keripik bayam, kajian media tanam hidroponik dengan media baglog dan arang sekam, penentuan parameter kinetika pada sintesis biodeisel, evaluasi non-destrustif asam lemak bebas dengan spektroskopi, uji kinerja alat pengering jagung, unjuk kerja mesin pemotong padi, dan evaluasi mutu biji melinjo dengan citra digital.

Pada kesempatan kali ini kami menyampaikan ucapan terima kasih yang sebesar-besarnya kepada para penulis atas kontribusinya dalam Jurnal TEP dan kepada para reviewer/penelaah jurnal ini atas peran sertanya dalam meningkatkan mutu karya tulis ilmiah yang diterbitkan dalam edisi ini.

Akhir kata, semoga Jurnal TEP ini dapat bermanfaat bagi masyarakat dan memberikan konstribusi yang berarti bagi pengembangan ilmu pengetahuan dan teknologi, khususnya di bidang keteknikan pertanian.

\section{Redaksi J TEP-Lampung}

ISSN (p): 2302-559X

ISSN (e): 2549-0818 


\section{Gencual TEKNIK PERTANIAN LAMPUNG}

Vol. 7 No. 2, Agustus 2018

Halaman

Daftar isi

Pengantar Redaksi

MODIFIKASI MESIN PENIRIS MINYAK DAN KELAYAKAN FINANSIAL PRODUKSI

KERIPIK BAYAM

Ahmad Thoriq, Totok Herwanto, Drupadi Ciptaningtyas

PENENTUAN NILAI PARAMETER KINETIKA ORDE SATU PADA SINTESIS BIODIESEL DARI MINYAK JELANTAH

Amieria Citra Gita, Agus Haryanto, Tri Wahyu Saputra, Mareli Telaumbanua

EVALUASI NON-DESTRUKTIF KANDUNGAN ASAM LEMAK BEBAS (ALB)

80-87

TANDAN BUAH SEGAR (TBS) KELAPA SAWIT DENGAN METODE NIR

SPEKTROSKOPI

Zaqlul Iqbal, Sam Herodian, Slamet Widodo

UJI KINERJA ALAT PENGERING SILINDER VERTIKAL PADA PROSES

$88-96$

PENGERINGAN JAGUNG (Zea mays ssp.mays)

Made Aditya Putra, Sandi Asmara, Cicih Sugianti, Tamrin

UNJUK KERJA MESIN PEMOTONG PADI (PADDY MOWER) SAAT PEMANENAN

PADI (Oryza Sativa L.) DI LAHAN BASAH

Siti Anisa, Siti Suharyatun, Oktafri, Sandi Asmara

EVALUASI MUTU BIJI MELINJO (Gnetum gnemon L.) MENGGUNAKAN

PENGOLAHAN CITRA DIGITAL

Slamet Widodo dan Muhammad Kalili

KAJIAN MEDIA TANAM HIDROPONIK DARI CAMPURAN BAHAN BAKU LIMBAH BAGLOG DAN ARANG SEKAM

Dyah Isworo, Sugeng Triyono, Agus Haryanto, Iskandar Zulkarnain 


\section{PEDOMAN PENULISAN ARTIKEL BAGI PENULIS}

1) Naskah: Redaksi menerima sumbangan naskah/tulisan ilmiah dalam bahasa Indonesia atau bahasa Inggris, dengan batasan sebagai berikut :

a. Naskah diketik pada kertas ukuran A4 $(210 \mathrm{~mm}$ x $297 \mathrm{~mm})$ dengan 2 spasi dan ukuran huruf Times New Roman 12pt. Jarak tepi kiri, kanan, atas, dan bawah masing-masing $3 \mathrm{~cm}$. Panjang naskah tidak melebihi 20 halaman termasuk abstrak, daftar pustaka, tabel dan gambar. Semua tabel dan gambar ditempatkan terpisah pada bagian akhir naskah (tidak disisipkan dalam naskah) dengan penomoran sesuai dengan yang tertera dalam naskah. Naskah disusun dengan urutan sebagai berikut: Judul; Nama Penulis disertai dengan catatan kaki tentang instansi tempat bekerja; Pendahuluan; Bahan dan Metode; Hasil dan Pembahasan; Kesimpulan dan Saran; Daftar Pustaka; serta Lampiran jika diperlukan. Template penulisan dapat didownload di http://jurnal.fp.unila.ac.id/index.php/JTP

b. Abstrak (Abstract) dalam bahasa Indonesia dan bahasa Inggris, tidak lebih dari 200 kata. Mengandung informasi yang tertuang dalam penulisan dan mudah untuk dipahami. Ringkasan (abstract) harus memuat secara singkat latar belakang, tujuan, metode, serta kesimpulan dan yang merupakan high light hasil penelitian.

c. Pendahuluan: memuat latar belakang masalah yang mendorong dilaksanakannya perekayasaan dan penelitian, sitasi dari temuan-temuan terdahulu yang berkaitan dan relevan, serta tujuan perekayasaan atau penelitian.

d. Bahan dan Metoda: secara jelas menerangkan bahan dan metodologi yang digunakan dalam perekayasaan atau penelitian berikut dengan lokasi dan waktu pelaksanaan, serta analisis statistik yang digunakan. Rujukan diberikan kepada metoda yang spesifik.

e. Hasil dan Pembahasan: Memuat hasil-hasil perekayasaan atau penelitian yang diperoleh dan kaitannya dengan bagaimana hasil tersebut dapat memecahkan masalah serta implikasinya. Persamaan dan perbedaannya dengan hasil perekayasaan atau penelitian terdahulu serta prospek pengembangannya. Hasil dapat disajikan dengan menampilkan gambar, grafik, ataupun tabel.

f. Kesimpulan dan Saran: memuat hal-hal penting dari hasil penelitian dan kontribusinya untuk mengatasi masalah serta saran yang diperlukan untuk arah perekayasaan dan penelitian lebih lanjut.

g. Daftar Pustaka: disusun secara alfabetis menurut penulis, dengan susunan dan format sebagai berikut: Nama penulis didahului nama family/nama terakhir diikuti huruf pertama nama kecil atau nama pertama. Untuk penulis kedua dan seterusnya ditulis kebalikannya. Contoh:

- Kepustakaan dari Jurnal:

Tusi, Ahmad, dan R.A. Bustomi Rosadi. 2009. Aplikasi Irigasi Defisit pada Tanaman Jagung. Jurnal Irigasi. 4(2): 120-130.

- Kepustakaan dari Buku:

Keller, J., and R.D. Bleisner. 1990. Sprinkle and Trickle Irrigation. AVI Publishing Company Inc. New York, USA.

h. Satuan: Satuan harus menggunakan system internasional (SI), contoh : $\mathrm{m}$ (meter), $\mathrm{N}$ (newton), ${ }^{\circ} \mathrm{C}$ (temperature), kW dan W (daya), dll.

2) PenyampaianNaskah:Naskah/karya ilmiah dapat dikirimkan ke alamatdalambentuksoft copyke :

Redaksi J-TEP(JurnalTeknikPertanianUnila)

Jurusan Teknik Pertanian, Fakultas Pertanian

Universitas Lampung

Jl. Sumantri Brodjonegoro No. 1

Telp. 0721-701609 ext. 846

Website : http://jurnal.fp.unila.ac.id/index.php/JTP

Email : jurnal.tep@fp.unila.ac.id atau ae.journal@yahoo.com

3) Selama proses penerimaan karya ilmiah, penelaahan oleh Reviewer, sampai diterimanya makalah untuk diterbitkan dalam jurnal akan dikonfirmasi kepada penulis melalui email.

4) Reviewer berhak melakukan penilaian, koreksi, menambah atau mengurangi isi naskah/tulisan bila dianggap perlu, tanpa mengurangi maksud dan tujuan penulisan. 


\title{
EVALUASI NON-DESTRUSTIF KANDUNGAN ASAM LEMAK BEBAS (ALB) TANDAN BUAH SEGAR (TBS) KELAPA SAWIT DENGAN METODE NIR SPEKTROSKOPI
}

\section{NON-DESTRUCTIVE EVALUATION OF FREE FATTY ACID (FFA) OF OIL PALM FRESH FRUIT BUNCH (FFB) USING NIR SPECTROSCOPY}

\author{
Zaqlul Iqbal $^{\circledR}$, Sam Herodian ${ }^{2}$, Slamet Widodo ${ }^{2}$ \\ ${ }^{1}$ Jurusan Keteknikan Pertanian, Fakultas Teknologi Pertanian, Universitas Brawijaya \\ ${ }^{2}$ Departemen Teknik Pertanian dan Biosistem, FakultasTeknologi Pertanian, Institut Pertanian Bogor \\ ${ }^{\otimes}$ Komunikasi penulis, Email : zaqluliqbal@ub.ac.id \\ DOI:http://dx.doi.org/10.23960/jtep-lv7i2.80-87
}

Naskah ini diterima pada 19 Juli2018; revisi pada 4 Agustus 2018;

disetujui untuk dipublikasikan pada 18 Agustus 2018

\begin{abstract}
Good quality of Crude Palm Oil (CPO) is indicated by low level of Free Fatty Acid (FFA). Processing over ripe oil palm Fresh Fruit Bunch (FFB) into CPO increases the level of FFA. Therefore, harvesting stage on field is crucial which determine the ripening stage of FFB. Generally, prediction of ripe FFB is conducted by using human vision which depending on its ability and condition. Therefore, a quantitative method which could predict the level of FFA objectively is required. In this research, a non-destructive method based on NIR spectroscopy was developed and examined for FFA prediction. Three steps were conducted to complete this research: obtaining reflectance spectrum data by using NIR Flex N-500, measuring FFA of palm oil fruit, and developing calibration model by using chemometrics. The result showed that the value of $R^{2}$ without data preprocessing was 0.236 , with $R P D$ and $P C$ was 1.27 and 2, respectively. First Derivative Savitzky Golay (DG1) gave the highest value of $R^{2}$ which was about 0.243 with both RPD was 1.17 and $P C$ was 2 . However, the result indicated that the model have not be used for predicting FFA of palm oil fresh fruit bunch yet.
\end{abstract}

Keywords: Palm oil, FFA, Chemometrics

\begin{abstract}
ABSTRAK
Kadar Asam Lemak Bebas (ALB) yang rendah merupakan salah satu indikator kualitas Crude Palm Oil (CPO) yang baik. Apabila Tandan Buah Segar (TBS) kelapa sawit yang lewat matang ikut diolah menjadi CPO, maka kadar ALB selama produksi dapat meningkat. Proses pemanenan menjadi titik krusial yang sangat mempengaruhi tingkat kematangan buah. Selama ini penentuan kematangan TBS kelapa sawit masih dilakukan secara visual yang bergantung kepada kemampuan dan kondisi pemanen buah sawit. Oleh karena itu, perlu dikembangkan suatu metode secara kuantitatif yang dapat memprediksi kadar ALB secara objektif. Pada penelitian ini, akan dikembangankan metode non-destruktif berbasis NIR spectroscopy yang akan dikaji sebagai metode untuk menentukan tingkat kematangan TBS berdasarkan kandungan ALB. Penelitian ini dibagi menjadi tiga tahapan, yaitu akuisisi data reflektansi spektrum TBS dengan NIR Flex N-500, pengukuran kadar ALB, dan pembangunan model kalibrasi dengan menggunakan kemometrik. Dari hasil pengembangan model didapatkan nilai $\mathrm{R}^{2}$ tanpa preprocessing sebesar 0.236, RPD sebesar 1.27 dan PC sebesar 2. Proprocessing First Derivative Savitzky Golay (DG1) memberikan nilai koefisien determinasi tertinggi yaitu sebesar 0.243, dengan nilai RPD sebesar 1.17 dan PC sebesar 2. Akan tetapi kualitas model kalibrasi yang dibangun tetap belum mampu menunjukkan kehandalan dalam memprediksi kandungan ALB tandan buah segar kelapa sawit.
\end{abstract}

Kata Kunci: Kelapa Sawit, ALB, Kemometrik 


\section{PENDAHULUAN}

Salah satu tantangan yang dihadapi untuk menjaga kualitas produksi Crude Palm Oil (CPO) adalah menjaga kandungan Asam Lemak Bebas (ALB) pada batas rendah. Salah satu penyebab yang menjadikan kadar ALB tinggi pada produksi sawit adalah Tandan Buah Segar (TBS) kelapa sawit yang dipanen tidak tepat tingkat kematangannya.

Pada buah lewat matang, kandungan ALB berada pada persentase yang tinggi, namun pada buah belum matang, kandungan minyak pada sawit rendah (Fauzi et al., 2007). Ditambah lagi, selama ini proses penentuan kematangan sawit menggunakan sistem fraksi kematangan yang ditentukan secara visual berdasarkan warna buah (Lubis AU, 1992). Padahal metode tersebut sangat bergantung pada kemampuan dan kondisi pemanen. Sehingga sering kali buah yang dipanen tidak sesuai standar pengolahan.

Oleh sebab itu, diperlukan suatu metode yang dapat mengetahui kandungan ALB secara kuantitatif. NIR spectroscopy merupakan salah satu metode non-destruktif yang dapat memprediksi kualitas internal bahan pertanian secara cepat dan tepat (Cayuela JA, 2017; Li M, 2017; Liu C, 2015). Metode ini juga dilaporkan dapat mengetahui perubahan tingkat kematangan buah dengan memprediksi kandungan kimia pada tahap kematangan (Jha SN, 2014; Watanawan C, 2014). Oleh sebab itu, tujuan dari penelitian ini adalah untuk mengetahui apakah metode NIR spectroscopy mampu menggantikan metode konvensional dalam memprediksi kandungan ALB pada TBS kelapa sawit dengan membangun model kalibrasi Partial Least Square (PLS).

\section{BAHAN DAN METODA}

\subsection{Bahan}

Bahan penelitian adalah TBS kelapa sawit klon Sungai Pancur (SP) yang ditentukan dari pohon dengan umur panen $4,5,6$, dan 7 bulan dihitung mulai terbentunya brondol sawit berdasarkan penaksiran mandor panen. Total sampel berjumlah 60 TBS dimana dari masing-masing umur terdiri atas 15 sampel. Sampel TBS secara langsung didapatkan dalam kondisi segar dari Perkebunan Cikasungka PTPN 8, Bogor, Jawa Barat.

\subsection{Alat}

Peralatan yang digunakan untuk akuisisi data spektrum NIR adalah Spektrometer NIRFlex N500 dengan panjang gelombang $1000-2500 \mathrm{~nm}$. Untuk menganalisis spektrum dengan regresi PLS digunakan software The Unscrambler $X$ 10.3 .

\subsection{Metoda}

\subsubsection{Penanganan Transportasi}

Total sampel yang digunakan adalah 60 buah Tandan Buah Segar (TBS) kelapa sawit. Dari TBS tersebut, diambil buah sawit kecil (brondol sawit) sebanyak masing-masing 3 butir dari tiga bagian: pangkal, tengah dan ujung buah (Gambar 1). Selama transportasi menuju laboratorium, sampel dikemas dalam plastik pembungkus dan ditempatkan di dalam ice box.

\subsubsection{Pengukuran Spektrum Reflektan NIR}

Tiap satu brondol sawit diambil data spektrumnya menggunakan fiber optic solid NIRFlex N-500 sebanyak satu kali ulangan (Gambar 2).

\subsubsection{Pengukuran Kandungan Asam Lemak Bebas (ALB)}

Kandungan ALB diuji dengan menggunakan prosedur SNI 01-3555-1998. Setelah pengambilan data spektrum dari 15 brondol sawit, diambil 5 gram serat sawit untuk diekstraksi. Sampel ditempatkan ke dalam labu erlenmeyer dan ditambah $50 \mathrm{ml}$ alkohol netral, kemudian dipanaskan hingga mendidih. Kemudian sampel didinginkan dan ditambahkan 3-5 indikator phenolpthealin ( $\mathrm{pp}$ ) kemudian dititrasi dengan larutan $\mathrm{NaOH} 0.1 \mathrm{~N}$. Kandungan ALB dihitung dengan menggunakan persamaan 1:

$$
\% A L B=\frac{M \times V \times T}{10 \times m}
$$




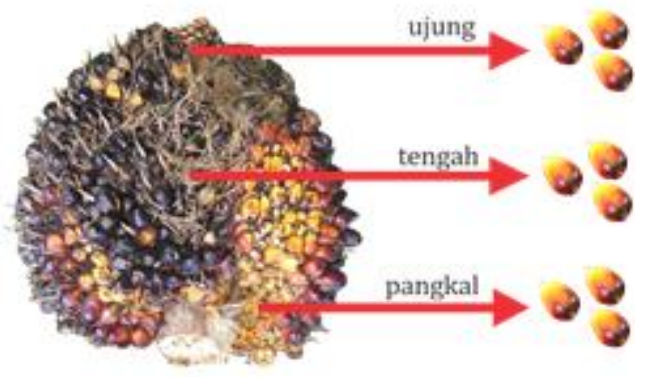

Gambar 1. Pengambilan sampel brondol sawit

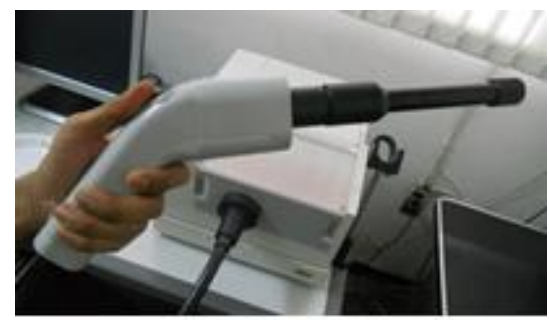

Gambar 2. Fiber optic solid NIRFlex N-500

dimana :

$V=$ volume $\mathrm{NaOH}$ yang diperlukan dalam penitaran (ml)

$T=$ Normalitas $\mathrm{NaOH}$

$m=$ Bobot contoh (gram)

$M=$ Bobot melekul asam lemak

\subsubsection{Kemometrik}

Data spektrum dan ALB sawit kemudian disandingkan sesuai dengan masing-masing sampel dan dari total sampel dibagi menjadi $2 / 3$ sebagai data kalibrasi dan $1 / 3$ menjadi data prediksi (William and Norris, 1990) atau masing-masing sebanyak 40 data dan 20 data. Kemudian dilakukan regresi Partial Least Square (PLS) dengan menggunakan software Unscramblrer X10.3. Model dibuat bedasarkan data spektrum sebagai prediktor dan ALB sebagai respon dengan konfigurasi full spektrum. Pembangunan model diperkuat dengan menggunakan cross validation 10 segmen dari 60 set data kalibrasi yang dipilih secara acak sebagai metode validasi model (Osborne et al., 1986). Diterapkan pula preprocessing data untuk memperbaiki kualitas sinyal spektrum yaitu: (First Derivative Savitzky Golay) DG1, (Standard Normal Variate) SNV, (Multiplicative Scatter Correction) MSC, dan (Orthogonal Signal Correction) OSC (Karoui et al., 2006; CAMO, 2012; Moghimi et al., 2010). Parameter yang digunakan dalam pembangunan model ini adalah koefisien determinasi $\left(\mathrm{R}^{2}\right)$, Root Mean Square Error of Cross-Validation (RMSECV), Root Mean Square Error of Prediction (RMSEP) serta Ratio of Prediction to Deviation (RPD).

\section{HASIL DAN PEMBAHASAN}

\subsection{Karakteristik Spektrum Reflektansi Buah Kelapa Sawit}

Karakteristik spektrum reflektansi buah kelapa sawit menunjukkan adanya lembah yang terlihat pada kisaran panjang gelombang $1190-1219 \mathrm{~nm}$, 1408-1470 nm, $1724 \mathrm{~nm}, 1886-1960 \mathrm{~nm}$, dan 2380-2500 nm (Gambar 3). Lembah yang terbentuk pada beberapa panjang gelombang mengindikasikan adanya senyawa kimia dominan yang terkandung pada buah sawit, meskipun tidak merepresentasikan adanya senyawa ALB, akan tetapi di kisaran panjang gelombang 1190-1219 nm memuat infromasi ikatan $\mathrm{CH}_{3}$ dan $\mathrm{CH}_{2} ; 1408-1470 \mathrm{~nm}$ memuat informasi ikatan $\mathrm{CH}_{2}$ dan $\mathrm{CH}$ (Osborne et al., 1986), dimana hal tersebut merupakan ikatan penyusun ALB.

Dari spektrum tersebut terlihat bahwa adanya noise dan sinyal yang tumpang tindih, sehingga diperlukan preprocessing data untuk memperbaiki sinyal spektrum agar mendapatkan model kalibrasi yang baik. 


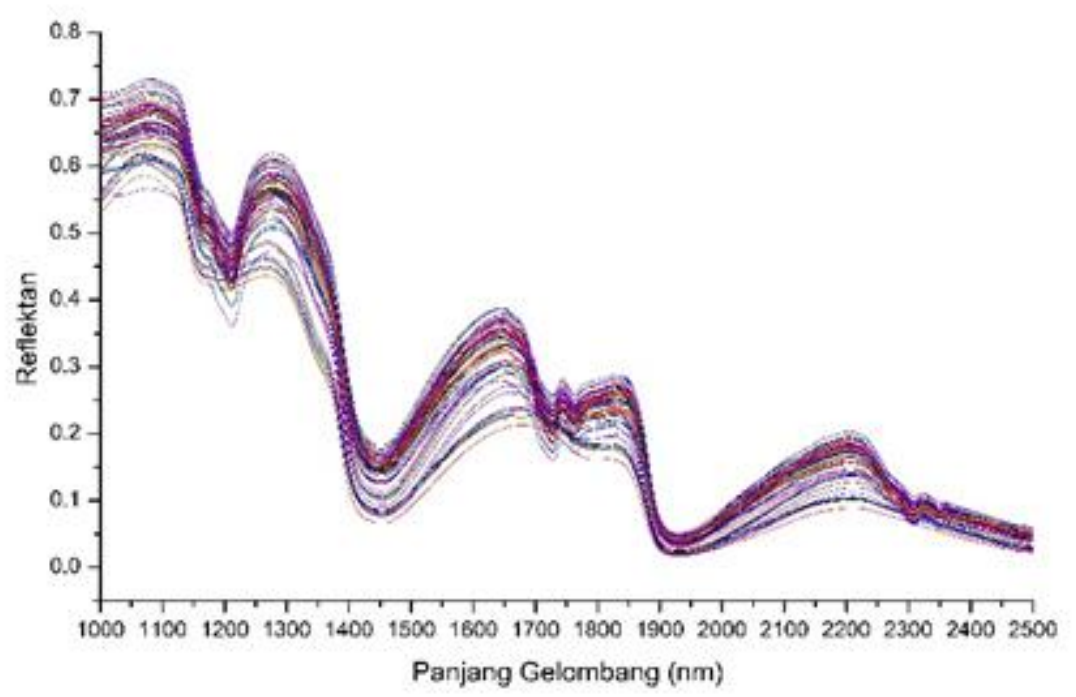

Gambar 3. Reflektansi spektrum original buah kelapa sawit

\subsection{Model kalibrasi ALB dengan regresi PLS}

Berdasarkan Gambar 4, terlihat bahwa model kalibrasi yang dibentuk tanpa preprocessing hanya memiliki nilai $\mathrm{R}^{2}$ sebesar 0.236 dengan nilai RPD sebesar 1.27 dan PC sebesar 2. Dari gambar tersebut juga terlihat bahwa sebaran nilai ALB sangat luas sehingga tidak membentuk regresi yang baik antara nilai prediksi dengan nilai aktual. Hal tersebut bertentangan dengan penelitian prediksi ALB Crude Palm Oil (CPO) yang menghasilkan nilai $\mathrm{R}^{2}$ hingga 0.997 dengan menggunakan panjang gelombang near infrared (Man Y.B.C, 1998; Naqiah SN, 2013). Hal mendasar yang mempengaruhi perbedaan tersebut adalah sampel yang digunakan merupakan buah segar.
Produk segar yang belum melalui proses penglohan dapat mengakibatkan kadar ALB berubah cepat akibat hidrolisis molekul lemak dan organisme pembusuk (Ketaren, 1986). Sampel berupa TBS yang dibagi menjadi 15 brondol sawit untuk merepresentasikan satu tandan sawit menyebabkan data spektrum yang didapat berjumlah besar. Set data yang besar menangkap segala kemungkinan perubahan pada sifat optik sampel (Zude et al., 2011) memiliki banyak kemungkinan. Ditambah lagi TBS kelapa sawit yang diambil berasal dari blok kebun yang berbeda-beda dan menyebabkan variasi data terlalu besar yang ternyata kurang baik diterapkan pada metode NIR spectroscopy (Arendse et al, 2018).
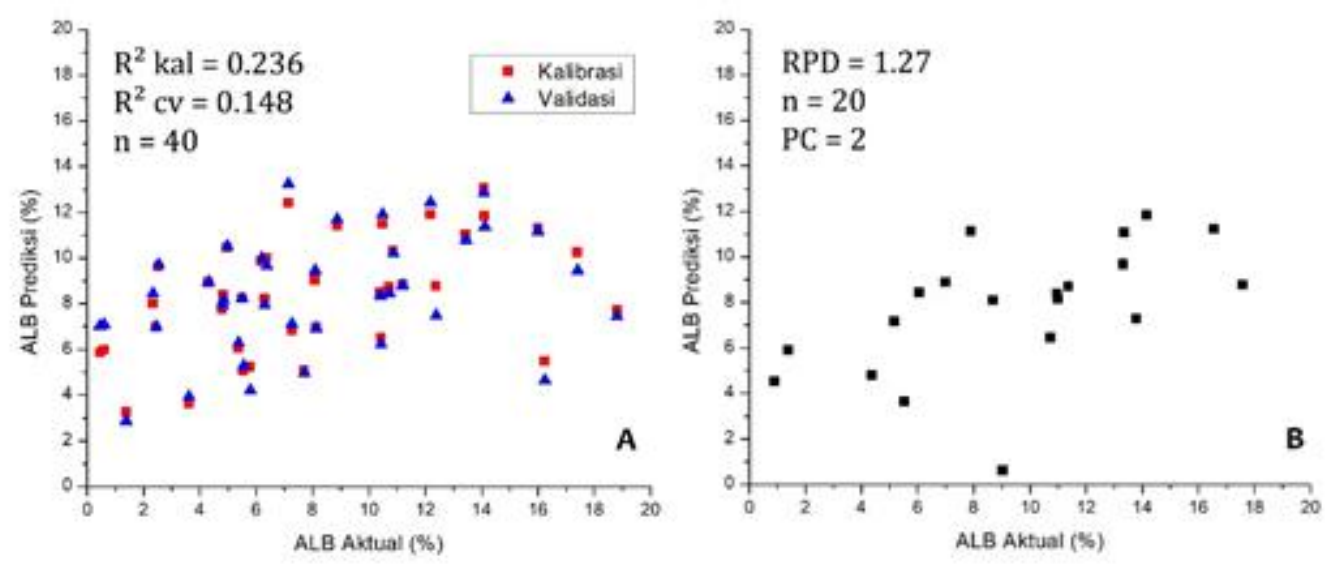

Gambar 4. (A) Grafik kalibrasi dan (B) prediksi PLS tanpa preprocessing 
Tabel 1. Deskripsi statistik ALB TBS kelapa sawit

\begin{tabular}{|c|c|c|c|c|c|c|}
\hline \multirow[b]{2}{*}{ Preprocessing } & \multirow[b]{2}{*}{$\mathrm{PC}$} & \multirow[b]{2}{*}{$\mathrm{R}^{2}$} & \multicolumn{2}{|c|}{ Kalibrasi } & \multirow{2}{*}{$\begin{array}{l}\text { Prediksi } \\
\text { RMSEP }\end{array}$} & \multirow[b]{2}{*}{ RPD } \\
\hline & & & RMSEC & $\begin{array}{c}\text { RMSEC } \\
\mathrm{V}\end{array}$ & & \\
\hline Original & 2 & 0.236 & 4.40 & 4.75 & 4.15 & 1.27 \\
\hline DG1 & 2 & 0.243 & 4.38 & 4.84 & 3.98 & 1.17 \\
\hline SNV & 3 & 0.211 & 4.47 & 4.94 & 4.55 & 1.02 \\
\hline MSC & 3 & 0.211 & 4.47 & 4.94 & 4.55 & 1.02 \\
\hline OSC & 1 & 0.234 & 4.40 & 4.63 & 4.16 & 1.12 \\
\hline
\end{tabular}

Tabel 1 menunjukkan bahwa terdapat variasi koefisien determinasi $\left(\mathrm{R}^{2}\right)$ yang terbentuk antara 0.211-0.243. Pada table tersebut, model awal dikalkulasi ulang dengan ditambahkan preprocessing DG1, SNV, MSC, dan OSC. Hasil menunjukkan bahwa untuk pretreatment SNV dan MSC tidak terlihat perbaikan model, namun dengan OSC terjadi perbaikkan model dimana faktor yang digunakan menjadi lebih sedikit. Untuk memberikan tingkat prediksi yang baik, diperlukan nilai $\mathrm{R}$ yang lebih besar dari 0.82 (Karoui et al., 2006). Sehingga hal tersebut menunjukkan tidak adanya korelasi yang baik antara data ALB aktual terhadap ALB prediksi. Salah satu kemungkinan tidak baiknya model kalibrasi yang dibangun, disebabkan oleh penanganan setelah melakukan akuisisi data spektrum, ALB sampel sawit tidak langsung diuji yang menyebabkan terjadinya perubahan kadar ALB secara alami sehingga spektrum buah sawit tidak memuat informasi ALB yang akurat.

\section{KESIMPULAN}

Terdapat lembah spektrum reflektansi buah kelapa sawit di kisaran panjang gelombang $1190-1219$ nm, $1408-1470 \mathrm{~nm}, 1724$ nm, 1886$1960 \mathrm{~nm}$, dan 2380-2500 nm. Model kalibrasi ALB dengan PLS menghasilkan $\mathrm{R}^{2}$ sebesar 0.243 yang mengindikasikan bahwa model tersebut belum dapat digunakan untuk memprediksi kadar ALB TBS kelapa sawit.

\section{DAFTAR PUSTAKA}

Arendse E, Fawole OA, Magwaza LS and Opara UL. 2018. Non-destructive prediction of internal and external quality attributes of fruit with thick rind: A review. Journal of Food Engineering, vol.21, pp.11-23
Badan Standarisasi Nasional. 1998. SNI 013555-1998 : Cara Uji Minyak dan Lemak.

CAMO. 2012. Method Reference the Unscrambler $X$. Dilihat 2 Maret 2018.[http:// w w w.camo.com/helpdocs / The Unscrambler Method References.pdf ]

Cayuela JA and García JF. 2017. Sorting olive oil based on alpha-tocopherol and total tocopherol content using near-infra-red spectroscopy (NIRS) analysis. Journal of Food Engineering. vol.202, pp.79-88

Fauzi Y, Widyastuti YE, Satyawibawa I, Hartono R.2007. Kelapa Sawit : Budidaya, Pemanfaatan Hasil dan Limbah, Analisis Usaha dan Pemasaran. Penebar Swadaya, Jakarta

Jha SN, Narsaiah K, Jaiswal P, Bhardwaj R, Gupta M., Kumar R and Sharma R. 2014. Nondestructive prediction of maturity of mango using near infrared spectroscopy. Journal of Food Engineering, vol.124, pp.152-157

Karoui R, Mouazen AM, Dufour E, Pillonel L, Schaller E, Baerdemaeker JD, and Bosset JO. 2006. Chemical Characterisation of European Emmental Cheeses by Near Infrared Spectroscopy Using Chemometric Tools. International Dairy Journal. vol.16, no.1, pp.1211-1217

Ketaren S. 1986. Minyak dan Lemak Pangan. Jakarta: UI-Press.

Li M, Pullanagari RR, Pranamornkith T, Yule IJ and East AR. 2017. Quantitative prediction of post storage "Hayward" 
kiwifruit attributes using at harvest VisNIR spectroscopy. Journal of Food Engineering. vol. 202, pp.46-55

Liu C, Yang SX and Deng L. 2015. Determination of internal qualities of Newhall navel oranges based on NIR spectroscopy using machine learning. Journal of Food Engineering, vol.161, pp.16-23

Lubis AU, 1992. Kelapa Sawit (Elaeis guineensis Jacq.) di Indonesia. Indonesian Oil Palm Research Institut (IOPRI), Medan, Indonesia

Man YBC, Moh MH. 1998. Determination of free fatty acids in palm oil by near-infrared reflectance spectroscopy. Journal of the American Oil Chemists' Society. vol.75, pp.557-562

Moghimi A, Aghkhani MH, Sazgarnia A and Sarmad M. 2010.Vis/NIR Spectroscopy and Chemometrics for the Prediction of Soluble Solids Content and Acidity $(\mathrm{pH})$ of.Kiwifruit. Biosystem Engineering. vol.106, no.1, pp.295-302

Naqiah SN and Herlina. 2013. Application of Near Infrared Spectroscopy for Assessment of Free Fatty Acid in Palm Oil.
Proceeding IEEE Conference on Open Systems (ICOS), Serawak, Malaysia, pp.3840

Osborne BG, Fearn T, Hindle PH. 1993. Practical NIR Spectroscopy With Application in Food and Baverage Analysis. Longman Singapore Publishers (Pte) Ltd, Singapore

Watanawan C, Wasusri T, Srilaong V, Wongs-Aree $\mathrm{C}$ and Kanlayanarat S. 2014. Near infrared spectroscopic evaluation of fruit maturity and quality of export Thai mango (Mangifera indica L. var. Namdokmai). International Food Research Journal. vol.21, no.3, pp.1073-1078

William P and Norris K. 1990.Near infrared technology in the agricultural and food industries. American Association of Cereal Chemist, Inc, St. Paul. USA.

Zude M, Pflanz M, Spinelli L, Dosche C and Torricelli A. 2011. Non-destructive analysis of anthocyanins in cherries by means of Lambert-Beer and multivariate regression based on spectroscopy and scatter correction using time-resolved analysis. Journal of Food Engineering. vol.103, no.1, pp.68-75. 
Evaluasi non-destrustif kandungan asam.... (Iqbal, dkk) 
